\title{
CREATING CUSTOMER RETENTION THROUGHT CUSTOMER INCENTIVES, TRUST AND COMPLAINT HANDLING (AT BMT AMANAH UMMAH IN KARTASURA)
}

\author{
Yona Septi Kartikawati, Istiatin, Sri Hartono \\ Faculty of Economics Faculty of Batik Surakarta University Study Program \\ J1. KH. Agus Salim No. 10, Telp. 0271-714751 Surakarta \\ e-mail : yonaseptik@gmail.com
}

\begin{abstract}
This study aims to determine and explain the simultaneous and partial influence of customer incentives, trust and complaint handling on customer retention at the BMT Amanah Ummah in Kartasura. This research method uses quantitative descriptive research design. With a population of 1.500 respondents. Withdrawal of the number of samples is determined by the Slovin formula and the results are 100 respondents. Sampling technique uses Instidental Sampling. Data collection using a questionnaire. Data analysis techniques used statistical analysis are multiple linear regression test, $\mathrm{F}$ test, $\mathrm{t}$ test and coefficient of determination. The results showed that customer incentives, trust and complaint handling simultaneously and significantly affected customer retention at the BMT Amanah Ummah in Kartasura. Customer incentives have a positive and significant effect on customer retention in the BMT Amanah Ummah in Kartasura. Trust has a positive and significant effect on customer retention in the BMT Amanah Ummah in Kartasura. Complaint handling has a positive and significant effect on customer retention at the BMT Amanah Ummah in Kartasura. The coefficient of determination or contribution of variable customer incentives, trust and complaint handling to customer retention in the BMT Amanah Ummah in Kartasura is 50.4\%. Suggestions from this research, BMT Amanah Ummah should in this case continue to improve and pay attention to factors that influence customer retention, namely customer incentives, trust and complaint handling.
\end{abstract}

Keywords: Customer Retention, Customer Incentives, Trust, Complaint Handling

\section{Introduction}

The development of Sharia Services Financial Cooperatives in Indonesia has increased a lot. At present the number of cooperative business units reaches 150.223 business units and 1.5 percent of them are Islamic finance savings and loan cooperatives (KSPPS). One of the sharia financial institutions that is experiencing rapid growth is Baitul mal wat tamwil BMT (www.ojk.co.id). Entering increasingly competitive business competition, a company's success in achieving optimal performance is constantly determined by how much a company or organization can have an advantage if it can produce goods and services that meet expectations and satisfy customers. As a newly established Islamic financial institution and the desire of people to become members is increasing. One of the alternative marketing strategies undertaken by BMT is by creating customer retention to improve quality, service performance and expand market segments (Krismawintari dan Kurniawati,2018). Customer retention has been widely 
used by several business companies to improve company performance (Sunarti, Suyadi dan Qonitat, 2018).

Maintaining old customers is the biggest focus, because it is considered more economical than looking for new customers and can further minimize costs (Ling, Nasab, dan Danesh, 2012). Companies must be able to understand customers more closely so that there is a good bond with customers in the long term and mutual benefit between the two parties (Zulkifli, 2012).

One of the factors is the formation of customer retention by providing incentives from banks which are very attractive to customers (Parno, Nursalim and Khairi, 2018). The incentives given to customers aim to generate an impetus in increasing transactions (Noviandari, Retnowati and Firmanzah, 2012). The results showed that incentives can affect customer retention.

Customer trust is one important factor in influencing the progress of the company which must provide comfort to its customers. Trust arises from a long process until both parties trust each other (Widiartanto, Farida and Sulistiani, 2015). Heriyadi, Listiana and Lay (2018) stated that trust had a positive and significant effect on customer retention. When trusting, consumer companies will continue to remain permanent customers in the long run.

Complaint handling is an effort to maintain good relations with customers. The company's ability to avoid service failures and complaints tends to have high expectations for overall customer satisfaction (Ndubisi, 2012). Complaint occurs because of customer dissatisfaction with the services provided by the company, if this is allowed to drag on it will have a negative impact on the company (Heriyadi, Listiana and Lay, 2018).

This research was conducted at KSPPS BMT Amanah Ummah Kartasura located at Jl. Slamet Riyadi 292 Gumpang, Kartasura, Sukoharjo, is engaged in Islamic financial institutions. KJKS BMT Amanah Ummah Kartasura is an Islamic microfinance institution that is operated on the principles of financing, investment, and savings according to profit sharing patterns (sharia).

The purpose of this study is to find out simultaneously and partially the variables of customer incentives, trust and complaint handling on customer retention at BMT Amanah Ummah Kartasura.

\section{Literature Review}

\subsection{Customer incentives}

Kotler (2009: 8) defines marketing is the main activity carried out by the company in maintaining the viability of the company, developing to get profits and long-term loyalty from customers. Kotler and Keller (2009: 23) one of the strategies carried out by the company by conducting a customer loyalty program, an effort to retain customers through the provision of incentives or rewards to customers. According to Kotler (2008: 219) states that providing incentives to customers is a way to create loyalty with the company, aiming to maintain and strengthen customer relationships.

\subsection{Trust}

Trust is the power of knowledge possessed by consumers and all conclusions consumers make that the product has objects, attributes and benefits (Sangadji and Sopiah, 2013: 204). Setiadi (2010: 14) trust is an idea that is owned by someone against a product. The idea that arises to someone is caused by a product that has been issued by the company. According to Turban (2010: 199) also defines that trust, which involves the willingness of someone to have confidence and the promise or statement of someone can be trusted by consumers. 


\subsection{Complaint Handling}

According to Suchaeri (2012: 67) defines customer complaints as an invaluable source of information for evaluating company performance improvement, opening customer complaints and complaints an opportunity for the company to fix the problem immediately. According to Tjiptono (2011: 164), stating that good handling of complaints provides an opportunity to turn a dissatisfied customer into a satisfied customer or even a lasting customer.

Lupiyoadi (2014: 247) complaints are statements of dissatisfaction with the services used. Customer complaints must be seen as positive input for the organization or company and provide opportunities for improvement of services offered to customers. Customers who are satisfied with the handling of complaints made by the company, will return to the same company. This is what forms customer retention (Kotler and Keller, 2012: 30).

\subsection{Customer Retention}

According to Kotler \& Keller (2009: 150-151) defining customer retention is one of the strategies in increasing the customer value base aimed at reducing the level of customer switching and increasing customer endurance for the company. According to Tjiptono (2011: 459) defines customer retention aimed at creating and retaining customers, many companies are far more prioritizing the creation of new customers rather than retaining existing customers. Retaining existing customers is considered more efficient, looking for new customers costs five times greater than retaining existing customers (Kotler and Keller, 2013: 20).

\section{Research Methods}

This research method uses quantitative descriptive research. Data analysis techniques use statistical analysis and explain and give an overview of the object under study and through sample data collected. The time used by researchers in conducting this study in October 2019 to January 2020. The population in this study was 1,500 respondents. The withdrawal of the sample size is determined by the Slovin formula and the results are 100 respondents. The sampling technique uses a non probability sampling technique that is incidental sampling is a sampling technique based on coincidence, ie anyone who incidentally / incidentally meets the researcher can be used as a sample, if viewed by people who happen to be found suitable as a source of data (Sugiyono, 2016: 85 ).

\section{Results And Discussion Research \\ 4.1 Data Analysis}

4.1.1 Classical Assumption Test

a. Normality test

For normality testing in this study using kolmogorov-smirnov in this normality test results are as follows: 
International Journal of Economics, Business and Accounting Research (IJEBAR)

Peer Reviewed - International Journal

Vol-4, Issue-2, 2020 (IJEBAR)

E-ISSN: 2614-1280 P-ISSN 2622-4771

http://jurnal.stie-aas.ac.id/index.php/IJEBAR

Table 1. Results of the Kolmogorov Smirnov normality test

\begin{tabular}{|c|c|c|c|}
\hline Kolmogorov-Smirnov $\boldsymbol{Z}$ & Significance & Limit & Information \\
\hline 1,126 & 0,158 & 0,05 & Normal \\
\hline
\end{tabular}

Source: Primary data processed in 2020.

The test results above prove that (K-S) $\mathrm{Z}$ is 1.126 and significant at 0.158 more than 0.05 , stated the data under study are normal division.

b. Multicollinearity Test

Multicollinearity test aims to test the regression model found a correlation between independent variables. A good regression model should not occur correlation between independent variables. Multicollinearity can be detected by looking at the tolerance value and Variance Inflation Factor (VIF). From the results of multicollinearity can be seen in the following table:

Table 2. Multicollinity Test Results

\begin{tabular}{|l|c|c|l|}
\hline \multicolumn{1}{|c|}{ Variable } & Tol & VIF & \multicolumn{1}{c|}{ Information } \\
\hline Customer Incentives & 0,891 & 1.123 & There is no multicollinearity \\
Trust & 0,845 & 1.184 & There is no multicollinearity \\
Complaint Handling & 0,805 & 1.242 & There is no multicollinearity \\
\hline
\end{tabular}

Source: Primary data processed in 2020

The results of this test indicate that the TOL values above 0.10 and VIF below 10 , it can be stated that the regression equation does not occur in multicollinearity.

c. Heteroscedasticity test

Heteroscedasticity test aims to test whether in the regression model there is an inequality of variance from the residuals of one observation to another. Heteroscedasticity test in this study uses the Glejser method, the results can be seen in the table below:

Table 3. Glejser Heteroscedasticity Test Results

\begin{tabular}{|l|c|c|c|}
\hline \multicolumn{1}{|c|}{ Variable } & Sig. & Limit & Information \\
\hline Customer Incentives & 0,051 & $>0,05$ & $\begin{array}{c}\text { Heteroscedasticity does } \\
\text { not occur }\end{array}$ \\
Trust & 0,265 & $>0,05$ & $\begin{array}{c}\text { Heteroscedasticity does } \\
\text { not occur }\end{array}$ \\
Complaint Handling & 0,070 & $>0,05$ & $\begin{array}{c}\text { Heteroscedasticity does } \\
\text { not occur }\end{array}$ \\
\hline
\end{tabular}

Source: Primary data processed in 2020. 
From the table above it can be explained that the variable customer incentives, trust and complaint handling have a tolerance value $>0.10$ and a VIF value $<0.10$. So the three variables do not occur heteroscedasticity.

\subsection{Hypothesis Testing}

\subsubsection{Analysis of Multiple Linear Regression}

Used to find out how much influence customer incentives (X1), trust (X2) and complaint handling (X3) have on customer retention. The following results of the multiple linear regression analysis are explained in the following table:

Table 4. Analysis of Multiple Linear Regression

\begin{tabular}{|l|c|c|c|c|}
\hline \multicolumn{1}{|c|}{ Variable } & $\boldsymbol{\beta}$ & $\mathbf{t}_{\text {hitung }}$ & Sig. & Information \\
\hline Customer Incentives & 0,139 & 2,144 & 0,035 & Significance \\
Trust & 0,356 & 3,721 & 0,000 & Significance \\
Complaint Handling & 0,483 & 0,5864 & 0,000 & Significance \\
\hline \multicolumn{2}{|l|}{ Constanta $: 0,854$}
\end{tabular}

Source: Primary data processed in 2020

From the multiple regression equation above, the analysis results contained in the calculation are:

Information:

$$
Y=0,854+0,139 X_{1}+0,356 X_{2}+0,483 X_{3}+e
$$

a. Constant (a) of 0.854 which means that if the variable Customer Incentives, Trust and Complaint Handling is 0 , then customer retention is 0.854 .

b. Regression coefficient (b1) $=0.139$ means that if the Customer Incentives increase, the customer retention in the BMT Amanah Ummah will increase by 0.139 with constant no change.

c. Regression coefficient $(\mathrm{b} 2)=0.356$ means that if Trust increases, then customer retention in the BMT Amanah Ummah will increase by 0.356 with constant no change.

d. Regression coefficient $(\mathrm{b} 3)=0.483$ means that if Complaint Handling increases, customer retention in the BMT Amanah Ummah will increase by 0.483 with constant no change.

e. The three variables above Customer Incentives, Trust and Complaint Handling have an impact on customer retention in the BMT Amanah Ummah.

\subsubsection{Coefficient of determination $\left(\mathbf{R}^{2}\right)$}

From the results of the coefficient of determination (R2) above, the magnitude of the effect is $48.8 \%$. It means customer retention on BMT Amanah Ummah in Kartasura by $48.8 \%$ is influenced by factors of customer incentives, trust and complaint handling. The remaining $51.2 \%$ is influenced by other factors that have not been taken into account in this study. 


\subsubsection{Simultaneous F Test}

Used to see or find out the significance of the effect of customer incentives, trust and complaint handling simultaneously on customer retention. The $\mathrm{F}$ test results obtained the calculated $F$ value is greater than $F$ table that is 32.506> 2.70 with a significance of 0,000 $<0.005$, then from these results Ho denies meaning customer incentives, trust, and complaint handling simultaneously and significantly influences customer retention in the Amanah BMT Ummah Kartasura.

\subsubsection{Partial t test}

Used to partially test the effect of independent variables consisting of customer insent, trust and complaint handling on the dependent variable, namely customer retention. Based on the results of the research analysis in table t conclusions can be drawn namely:

1. Variable customer incentive value results $t$ value $(2,144)>t$ table $(1,985)$ significant partial conclusions can be drawn that customer incentives have a positive and significant effect on customer retention at the BMT Amanah Ummah in Kartasura.

2. The variable trust the results of the $t$ value $(3,721)>t$ table $(1,985)$ significant 0,000 $<0.05$ can be concluded partially trust has a positive and significant effect on customer retention in the BMT Amanah Ummah in Kartasura.

3. Variable complaint handling results $t$ value (5.864)> t table (1.985) significant 0.000 $<0.05$ can be concluded partially complaint handling has a positive and significant effect on customer retention at the BMT Amanah Ummah in Kartasura.

\subsection{Discussion}

The effect of simultaneous customer incentives, trust and complaint handling on customer retention at the BMT Amanah Ummah in Kartasura.

Based on the results of the F test it is known that Fcount> Ftable $(32.506>2.70)$ and a significance of $0.000<0.05$, then $\mathrm{Ho}$ is rejected $\mathrm{H} 1$ accepted. This means that customer incentives, trust and complaint handling simultaneously and significantly affect customer retention. These results prove the higher the customer incentives, trust and complaint handling, the customer retention will increase significantly.

\section{Effect of customer incentives on customer retention on BMT Amanah Ummah in Kartasura. \\ Based on the $t$ test analysis obtained ttable $<\mathrm{t}$ count $(1.985<2.144)$, the significance value of $0.000<0.05$ and the regression coefficient has a positive value of 0.139 , then Ho is rejected $\mathrm{H} 2$ is accepted. This means that customer incentives have a positive and significant effect on customer retention. If the existing customer incentives are more attractive and numerous, then customer retention will increase. This study is in line with previous research conducted by Noviandari, Retnowati and Firmanzah (2012) customer incentives have a positive and significant effect on customer retention. The incentives provided will be of value more for the company because of the provision of incentives to make members survive in the long term and loyal to the company.}

\section{Effect of Trust on customer retention on the BMT Amanah Ummah in Kartasura}

Based on the analysis of $t$ test results obtained t table $<t$ count $(1.985<3.721)$, the significance value of $0.000<0.05$ and the regression coefficient has a positive value of 0.356 , 
then Ho is rejected $\mathrm{H} 3$ is accepted. This means that trust has a positive and significant effect on customer retention. If the trust is getting better, then customer retention will increase. This study is in line with previous research conducted by Septrizola, Evanita, and Nanda (2019). Trust has a positive and significant effect on customer retention. Trust can show the existence of a good system in the company and the trust given by consumers is one of the initial keys where the goals made by the company will be achieved.

\section{Effect of Complaint Handling on customer retention at the BMT Amanah Ummah in Kartasura}

Based on the analysis of $t$ test results obtained $t$ table $<\mathrm{t}$ count $(1.985<5.864)$, a significance value of $0.000<0.05$ and the regression coefficient has a positive value of 0.483 , then $\mathrm{Ho}$ is rejected $\mathrm{H} 4$ is accepted. This means that complaint handling has a positive and significant effect on customer retention. If the complaint handling that is given gets better in overcoming it, then customer retention will increase. This study is in line with previous studies conducted by Runtuwene, Pio and Lompoliuw (2019) complaint handling has a positive and significant effect on customer retention. Relationship of complaint handling with customer retention is influenced by the experience of consumers who make complaints can be resolved properly, the complaints from consumers can make the company better.

\section{Conclusions And Suggestions}

\subsection{Conclusions}

Based on the results of research and discussion, several conclusions can be drawn as follows:

1) F test results show there is a simultaneous and significant influence of customer incentives, trust and complaint handling on customer retention at the BMT Amanah Ummah in Kartasura.

2) $t$ test results show:

a. Customer incentives have a positive and significant effect on customer retention in the BMT Amanah Ummah in Kartasura.

b. Trust has a positive and significant effect on customer retention in the BMT Amanah Ummah in Kartasura.

c. Complaint Handling has a positive and significant effect on customer retention at the BMT Amanah Ummah in Kartasura.

\subsection{Suggestions}

1) BMT Amanah Ummah should provide incentives for members as a whole. Because the provision of incentives as a whole will make all members will survive on the BMT Amanah Ummah.

2) BMT Amanah Ummah should provide incentives for members as a whole. Because the provision of incentives as a whole will make all members will survive on the BMT Amanah Ummah.

3) BMT Amanah Ummah should provide incentives for members as a whole. Because the provision of incentives as a whole will make all members will survive on the BMT Amanah Ummah. 


\section{References}

Heriyadi, Listiana, E. dan Lay, Y.N. 2018. Analisis Pengaruh Service Quality, Personal Selling dan Complaint Handling serta Trust terhadap Customer Retention (Survei Nasabah Tabungan Bank Harda Internnasional Cabang Pontianak). Volume 7 Nomor 2.

Kotler.P. 2008. Prinsip-Prinsip Pemasaran 2. Edisi Keduabelas. Jakarta : Erlangga.

Kotler.P. dan Keller.L.K. 2009. Manajemen Pemasaran. Jakarta : Erlangga.

Kotler, Philip and Kevin Lane Keller. 2012. Manajemen Pemasaran. Edisi 13 Jilid 1 dan 2. Jakarta: Erlangga.

Krismawintari, D.P.N., dan Kurniawati, E.S.N. 2018. Pengaruh Pemasaran Relasional Terhadap Kepuasan Konsumen Dan Customer Retention Pada Toko Herbal Angelo Store Ubud Bali. Volume 13 Nomor 1.

Ling, C.K., Nasab, A.S., dan Danesh, N.S. 2012. The Study of Customer Satisfaction, Customer Trust and Switching Barriers on Customer Retention in Malaysia Hypermarkets. International Journal of Business and Management Volume 7 Nomor 7 Halaman 141-150.

Lupiyoadi.R. 2014. Manajemen Pemasaran Jasa. Edisi 3. Jakarta : Salemba Empat.

Ndubisi, O.N. 2012. Relationship quality antecedents : The Malaysian retail banking perspective. International Journal of Quality \& Reliability Management · September Volume 29 Nomor 6 Halaman 829-845.

Noviandari, I. Retnowati, N. dan Firmanzah, F. 2012. Pengaruh Point Reward, Undian Berhadiah dan Asuransi Terhadap Loyalitas Pelanggan PT ISM Bogasari Flour Mills Surabaya. Jurnal Manajemen Branchmarck. Volume 4. Halaman 168-178.

Parno, Nursalim, E., dan Khairi. 2018. Pengaruh Pendapatan Bagi Hasil dan Pemberian Bonus terhadap Loyalitas Nasabah di Bank Syariah Mandiri Kantor Cabang Sangatta. International Journal Ihya' 'Ulum Al-Din Volume 20 Nomor 1 Halaman 17-40.

Runtuwene, F.R., Pio, J.R., dan Lompoliu, M.S.T. 2019. Faktor-Faktor Yang Mempengaruhi Customer Retention Di PT. Erafone Mega Mall Manado. Jurnal Administrasi Bisnis Volume 9 Nomor 1 Halaman 114-121.

Sangadji dan Sopiah. Perilaku konsumen : Pendekatan Praktis disertai Himpunan Jurnal Penelitian. Yogyakarta : Andi.

Septrizola, W., Evanita, S., dan Nanda, R. 2019. Pengaruh Kepuasan Pelanggan, Hambatan Beralih, dan Kepercayaan Pelanggan Terhadap Retensi Pelanggan Pengguna Kartu Simpati Pada Mahasiswa Universitas Negeri Padang. Jurnal Kajian Manajemen dan Wirausaha Volume 01 Nomor 01 Halaman 207-217.

Suchaeri, H. 2012. Total Customer: Percepatan Laba Sepanjang Masa. Solo: Metamograf. 
Sunarti., Suyadi, I., dan Qonitat, N.N. 2018. Pengaruh Kepuasan Pelanggan, Switching Barrier dan kepercayaan Merek Terhadap Customer Retention (Survei pada Mahasiswa S1 Mahasiswa Universitas Brawijaya Malang Pelanggan Produk Merek Wardah). Jurnal Administrasi Bisnis (JAB) Volume 55 Nomor 2 Halaman 57-67.

Tjiptono. F. 2011. Manajemen Pengaduan (Komplain). Yogyakarta: Andi.

Turban, E. David King. Jae Lee. Ting-Peng. And Decorrah C. Turban 2010. Electronic commerce. Managerial perspective global. Edition (6 edistion). New Jersey: Pearson.

Widiartanto,. Farida, N. dan Sulistiani, F. 2015. Pengaruh Kepercayaan, Komitmen dan Komunikasi Terhadap Retensi Pelanggan Dengan Kepuasan Pelanggan Sebagai Variabel Intervening. Diponegoro Journal of Social and Political of Science.

Zulkifli, 2012. Relationship Marketing Terhadap Customer Retention dan Customer Loyality Pada Nasabah Bank Mega, Tbk. Malang. Jurnal Akuntansi dan Manajemen Volume 1 Nomor 1 Halaman 55-68.

www.ojk.go.id Diakses tanggal 4 Februari 2016. 